\title{
Missão cumprida e agradecimentos
}

http://dx.doi.org/10.1590/1807-55092014000400531

O último número de 2014 da RBEFE representa para todos os envolvidos nessa árdua tarefa de gerir um periódico brasileiro um sentimento gratificante de realização. A qualidade dos artigos publicados vem crescendo de maneira significativa e reflete o trabalho conjunto de autores, revisores, editores associados, e equipe administrativa da RBEFE. Cada um com seu respectivo e importante papel contribui de forma absolutamente voluntária, motivados por um único objetivo: a melhoria qualitativa da Revista e a sua consequente contribuição para o avanço do conhecimento.

Quero neste momento agradecer imensamente aos Editores Associados, Prof. Hamilton Roschel, Profa. Ana Cristina Zimmermann e Prof. Luciano Basso, pelo trabalho dedicado, profissional, competente, pautado no esforço e no compromisso com a comunidade, com o único propósito de assegurar a qualidade da RBEFE, e sua consequente contribuição para o desenvolvimento e avanço de nossa área. O esforço voluntário dos Editores Associados e o comprometimento com esta importante função devem ser destacados e reconhecidos. A valorização dos periódicos brasileiros deve ser alvo de consideração e preocupação para toda a comunidade científica, e o trabalho de nossos Editores Associados tem um papel central neste contexto. Em nome de toda a comunidade, recebam meus agradecimentos! Obrigado pelo apoio de sempre e pelas intermináveis horas de dedicação a nossa RBEFE. Meus agradecimentos especiais para a Lúcia. A Maria Lúcia Vieira Franco, responsável pelo nosso "escritório editorial", é o coração da RBEFE. Seu trabalho de longos anos dedicados a RBEFE possibilitou não somente a sobrevivência da RBEFE ao longo de sua história, mas também, criou todas as condiçôes necessárias para o crescimento e desenvolvimento da RBEFE e sua consolidação como um dos mais importantes e tradicionais periódicos de nossa área. Sem a "Lúcia”, tenho certeza que não teríamos avançado e certamente não teríamos conseguido ultrapassar e superar barreiras e obstáculos que muitas vezes nos pareceram instransponíveis. Lúcia, meu muito obrigado; estou certo de que todos os autores, revisores, editores e comunidade em geral gostariam, nesse instante de ter a oportunidade de agradecêla. Agradeço também a Solange Alves Santana, responsável pelo brilhante trabalho de criação e divulgação da RBEFE nas mídias sociais, e que vem colaborando em todos os sentidos para com a nossa RBEFE. Um importante "reforço" para o nosso "quadro"! Por fim, nesse encerramento de ciclo, devo agradecer aos revisores e autores, que com contribuiçóes espontâneas e de qualidade contribuem de forma imensurável para o avanço e qualificação da RBEFE. Desejo a todos, uma ótima leitura dos artigos do número 4. A RBEFE espera contar com vossas valiosas colaboraçóes neste novo ciclo que se inicia. A missão está cumprida. Mais do que isto, estou certo que a RBEFE está preparada para o novo ciclo que se inicia e os desafios que virão. Até breve.

\author{
Prof. Dr. Alexandre Moreira
}

Blog da RBEFE - http://rbefe.blogspot.com.br
Facebook - http://wwww.facebook.com/reveefe
Twitter - https://twitter.com/RBEFE

Rev Bras Educ Fís Esporte, (São Paulo) 2014 Out-Dez;28(4):531 • 531 